\title{
Atrial Natriuretic Factor During the Perinatal Period: Equal Depletion in Both Atria ${ }^{1}$
}

\author{
LAWRENCE M. DOLAN, CAROLYN A. YOUNG, JANE C. KHOURY, AND \\ DOUGLAS J. DOBROZSI \\ Division of Endocrinology [L.M.D., C.A.Y., D.J.D.J, Children's Hospital Medical Center, and Division of \\ Epidemiology and Biostatistics [J.C.K.], University of Cincinnati, Cincinnati, Ohio 45229
}

\begin{abstract}
Data in the literature concerning atrial natriuretic factor (ANF) physiology in the fetus and newborn, although limited, suggest significant activity during the perinatal period. To characterize further ANF physiology during this time, we documented immunoreactive ANF (IRANF) concentrations in the right and left atria before and immediately after birth as well as in the hearts of immature and adult rats. There was a significant decrease in the concentration of IR-ANF in both right and left atria on the d before birth that persisted for the first $\mathbf{4 8} \mathrm{h}$ of life [d 20 fetal right $570(106,90)$, left $580(86,75)$; 21 fetal right $270(70,55)$, left $214(117,75) ; 1$ d right $206(39,33)$, left 229 (41, 35); 2-d right $352(35,32)$, left $237(26,23)$ $\{$ geometric mean (upper SE, lower SE) in ng $\mathrm{ANF} / \mathrm{mg}$ protein $\}$ ]. Repletion of ANF stores began in the right atrium on $d 2$ of life and in the left atrium between $d 2$ and 5. The highest levels of IR-ANF were observed at d 15 [d 5 right $1439(53,51)$, left $1547(83,79)$; d 15 right 2034 $(90,86)$, left $1943(108,102)$; adult right $1380(119,109)$, left $963(118,105)]$. In contrast to normal adult animals, factors mediating the observed change affect both atria equally during the perinatal period. The concentration of IR-ANF in the right and left atrium of the fetal, newborn, and immature animals was equal. These data document significant alterations in intraatrial IR-ANF concentrations in the perinatal period. The changes in tissue concentration reflect an alteration in the synthesis/release relationship that may be either a response to or evidence of involvement in the modulation of intravascular vol at the initiation of extrauterine life. (Pediatr Res 25:339-341, 1989)
\end{abstract}

\section{Abbreviations}

ANF, atrial natriuretic factor

IR-ANF, immunoreactive atrial natriuretic factor

ANF, a peptide synthesized and secreted by atrial myocytes, has potent natriuretic, diuretic, vasodilatory, and antimineralocorticoid properties $(1-7)$. These characteristics suggest that ANF may play a significant role in salt and water homeostasis and in blood pressure control $(1,8)$.

Data in the literature concerning ANF physiology in the fetus

Received June 16, 1988; accepted November 15, 1988.

Correspondence and reprints L.M. Dolan, M.D., Division of Endocrinology, Children's Hospital Medical Center, Elland \& Bethesda Avenues, Cincinnati, OH 45229.

Supported by Trustee Research Support Grant, Children's Hospital Research Foundation, Cincinnati, $\mathrm{OH}$.

1 Presented in part at the Second World Congress on Biologically Active Atrial Peptides, New York, NY, May 1987, and Society for Pediatric Research, Anaheim, CA, April 1987. and newborn, although limited, suggest significant activity during the perinatal period. IR-ANF is present in the fetal rat heart shortly after formation of the four chamber heart, and at $20 \mathrm{~d}$ of gestation, levels of IR-ANF in plasma are markedly higher than in the adult rat $(9,10)$. During late gestation of the fetal sheep, intravascular expansion causes an increased concentration of plasma IR-ANF (11). In human newborns, arterial cord plasma levels and venous plasma concentrations obtained during the first $4 \mathrm{~d}$ of extrauterine life are reported to be greater than plasma levels in adults (12-14). Unexpectedly, IR-ANF has also been found in high concentrations in the 20 -d fetal rat ventricle, with a marked decrease occurring in the first few days of life $(10,15)$. The significance of ventricular ANF remains unclear.

To define more clearly ANF physiology during the perinatal period, we measured IR-ANF concentrations in the right and left atria before and immediately after birth as well as in the hearts of immature and adult rats. We then compared ANF levels between right and left atria and among age groups.

\section{MATERIALS AND METHODS}

Tissue harvest. Pregnant Sprague-Dawley rats at 20 and $21 \mathrm{~d}$ of gestation (term $=21-22 \mathrm{~d}$ ), pups at 1, 2, 5, and $15 \mathrm{~d}$ of age, and adult nonpregnant female animals (Harlan, Indianapolis. IN) were killed by stunning and decapitation. After the hearts of the fetuses, pups, and adult animals were removed, individual atria were dissected free, frozen in liquid nitrogen, and stored at $-70^{\circ} \mathrm{C}$ until extraction. Tissue from fetuses and pups was harvested from two litters at each age.

Extraction and recovery of ANF. Frozen tissue samples were partially thawed on ice then individually processed. We added 2 $\mathrm{mL}$ of hot $\left(100^{\circ} \mathrm{C}\right) 1.0 \mathrm{M}$ acetic acid to each specimen. The samples were homogenized for $60 \mathrm{~s}$ (Tissumizer, Tekmar, Cincinnati, $\mathrm{OH}$ ), placed in boiling water for $10 \mathrm{~min}$, cooled on ice. and centrifuged at $30000 \times g$ for $30 \mathrm{~min}$ at $4^{\circ} \mathrm{C}$. An aliquot of the supernatant was lyophilized for subsequent RIA and the remainder stored at $-70^{\circ} \mathrm{C}$ for protein determination and recov-. ery. Protein concentration was measured by the method of Lowry' et al. using BSA as the standard (Sigma Chemical Co., St. Louis, MO) (16).

Recovery of IR-ANF from the acid extraction procedure was; quantified using extracts of both right and left atria from each age group. Selected samples were separated into two equal vol. A known amount of unlabeled ANF (two to three times greater than concentration present in the extract) was added to one portion and to an equal vol of RIA buffer. All extracts were processed as previously described, and the amount of ANF in the extracts and buffer samples was determined by RIA. Recov.ery was calculated as the difference between samples with and without added ANF, divided by the concentration of ANF in the buffer samples.

RIA. Lyophilized tissue extracts were reconstituted in RIA 
buffer $(0.1 \mathrm{M}$ sodium phosphate, $0.05 \mathrm{M} \mathrm{NaCl}, 0.1 \% \mathrm{BSA}, 0.1 \%$ Triton $\mathrm{X}-100,0.01 \%$ sodium azide, $\mathrm{pH} 7.4)$. RIA was performed using the double antibody method (17). Rabbit anti-hANF, ${ }^{125} \mathrm{I}-$ $\mathrm{hANF}$, and $\alpha$-hANF standard were obtained from Peninsula Laboratories (Belmont, CA). Goat antirabbit $\gamma$-globin was purchased from Antibodies Inc. (Davis, CA). The cross-reactivity of rabbit anti-hANF is $100 \%$ with rat ANF (Ile ${ }^{12} \alpha$-hANF), $100 \%$ with rat atriopeptin III, $5 \%$ with rat atriopeptin II, and $0 \%$ with rat atriopeptin I. The final dilution of ANF antibody was 1:120000. The sensitivity of the assay in our laboratory is 2.6 $\mathrm{pg} /$ tube. The intraassay and interassay coefficients of variation are $7 \%(n=9)$ and $11 \%(n=34)$, respectively.

Analysis. To normalize the distribution of the data, a log transformation was performed before the analysis. To test for differences in IR-ANF concentrations at various ages and between the right and left atria, an ANOVA was performed using the Student-Newman-Keuls test for a posteriori comparisons. A paired $t$ test was used to test for right-left differences at each age. The SAS (SAS Inc., Cary, NC) computer program package was used for data management and analysis. A value of $p<0.05$ was considered significant.

\section{RESULTS}

The recovery of ANF in the acid extracts of the right and left atrial samples was determined (see Materials and Methods) in three samples from each atria at each time period. The range of the recoveries was $71.3 \%$ to $104.2 \%$; the mean was $88.4 \pm 2.3 \%$ $(\bar{X} \pm \mathrm{SE})$. Reported concentrations of IR-ANF were corrected for mean recovery of $\alpha$-hANF from the right and left atria at each age. Samples from both atria at each age diluted in parallel to the standard curve of the RIA as previously reported (9). Samples from either atria which did not produce values on the acceptable portion of the standard curve for either the protein determination or ANF RIA were excluded. The concentrations of IR-ANF [geometric mean (upper, lower)] in the right and left atria at each age are displayed in Figure 1.

Levels of IR-ANF decreased in both the right and left atria from d 20 to $\mathrm{d} 21$ of gestation and remained lower than $\mathrm{d} 20$ through the first $2 \mathrm{~d}$ of life $\left(^{*}\right)$. In the right atrium, the concentration rose between $\mathrm{d} 1$ and $\mathrm{d} 2\left(^{* *}\right)$, but there was no difference between the same ages in the left atrium. After $\mathrm{d} 2$, the amount of IR-ANF increased in both. Levels in the right and left atria on $\mathrm{d} 5$, the right and left atria on d 15, and the right atria of adults were higher than concentrations during the perinatal period $(\mathbf{\Delta})$. In the adult left atria, however, the amount of IRANF was lower than the left atrial concentrations on d $15(\bullet)$. In addition, the IR-ANF level in the left atria of adults was not different from that of the $20-d$ fetus.

There was no difference in the concentration of IR-ANF between the right and left atria at the same age except on $\mathrm{d} 2$ of life (ם). In the adult animals, right atrial concentration was greater than left atrial concentration, but this difference did not reach statistical significance $(p<0.0559)$.

\section{DISCUSSION}

This study documents a significant decrease in the concentration of IR-ANF in both right and left atria on the d before birth that persists for the first $48 \mathrm{~h}$ of life. Repletion of ANF stores begins in the right atrium by $\mathrm{d} 2$ and in the left atrium between $\mathrm{d} 2$ and 5. The highest observed concentration of IR-ANF occurs on d 15. In contrast to normal adult animals, factors mediating the observed changes effect both atria equally during the perinatal period. The concentration of IR-ANF in the right and left atrium of the fetal, newborn, and immature animals is equal.

The decrease in the concentration of intraatrial IR-ANF on $d$ 21 of gestation suggests that factors modulating the concentration of ANF are active before extrauterine life. The stimuli responsible for the change in ANF concentration in the fetal rat are unknown; however, data from the sheep and humans suggest that the recognized stimuli of ANF secretion in adults (elevated
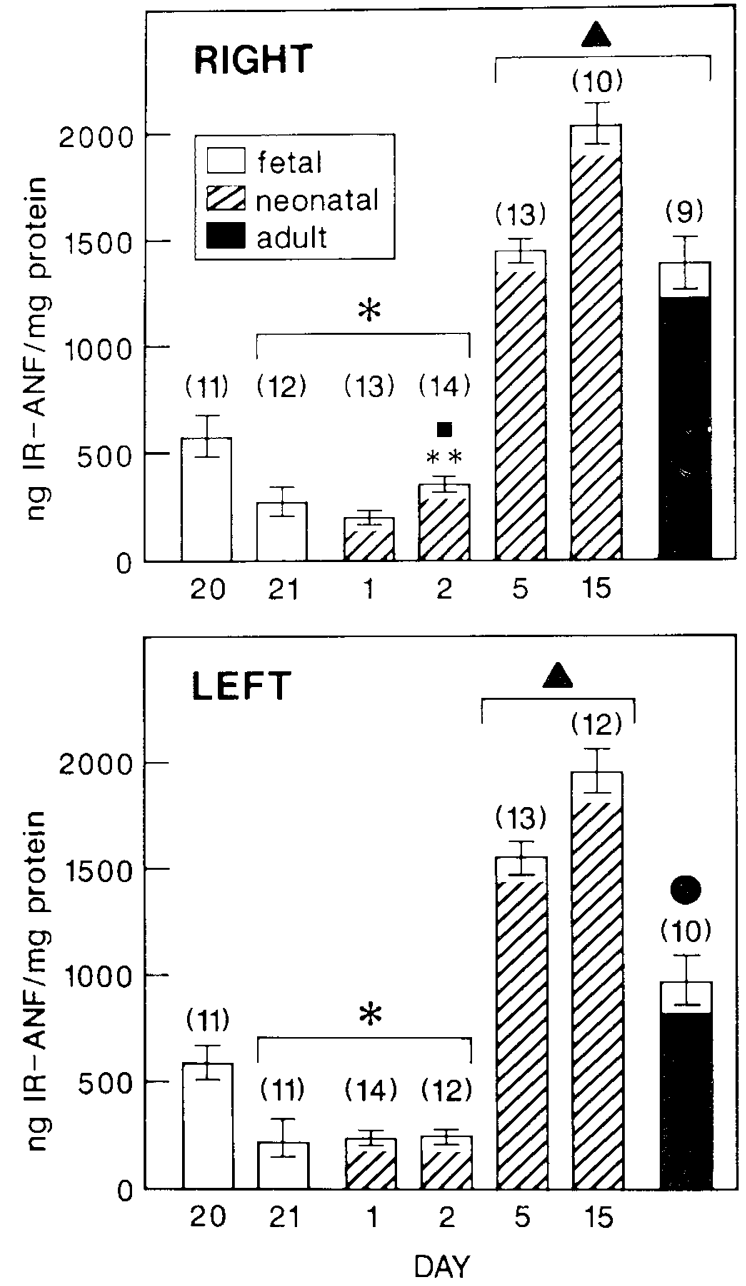

Fig. 1. Immunoreactive atrial natriuretic factor concentration in acid extracts from right and left atria at various ages. Geometric mean (upper $\mathrm{SE}$, lower SE). SE are uneven due to $\log$ transformation. () $=n ; *=$ different than Day 20 to gestation; ${ }^{* *}=$ different than day 1 of life; $\boldsymbol{\Lambda}=$ different than day 20 fetal through day $2 ; \boldsymbol{\theta}=$ different than day 15 ; $\boldsymbol{\square}=$ different than left atria of same age $(p<0.05)$.

intraatrial pressure or vol and increased heart rate) may be active in late gestation and the perinatal period (1). Exogenous vol expansion in late gestation of the fetal sheep stimulates ANF release (11). Despite the fact that physiologic intravascular expansion has not been shown to mediate a similar response, reports suggest that events before birth may be associated with net fluid shift into the intravascular space. Specifically, decreased lung fluid production has been documented in the lamb $2 \mathrm{~d}$ before delivery (18). In addition, increased intrauterine hydrostatic pressure associated with labor could expand the intravascular vol and increase ANF secretion as observed with water immersion therapy $(19,20)$. At birth, hemodynamic changes result in a rise in intraatrial pressure (20). Finally, marked alterations in heart rate are associated with uterine contractions during labor (20). Thus, the known stimuli of ANF release may influence intraatrial ANF concentration in the perinatal period.

Normal adult animals respond to physiologic and pharmacologic stimuli by the release of ANF from the right atrium (2124). A similar conclusion was reached concerning the fetal rat. Investigators administered indomethacin to rat dams on d 20 of gestation and subsequently documented a decrease in the concentration of ANF in right fetal atrium but no change in the left fetal atrium (10). The response was presumed secondary to vol and pressure changes in the right atrium associated with closure of the ductus arteriosus (10). In the present study, the equal response of both atria suggests that the aforementioned changes 
in blood flow and pressure are not the sole mediators of depletion of intraatrial ANF in the perinatal period. Either the fetus and newborn respond differently than adults to the known physiologic stimuli of ANF release or other, as yet unrecognized, factors are operative only during the perinatal period that result in an equal response of both atria.

Repletion of ANF stores began in the right atrium on $\mathrm{d} 2$ of life and in the left atrium between $\mathrm{d} 2$ and 5 . This suggests that the factors stimulating the depletion of ANF in both atria are less effective or less active on $\mathrm{d} 2$ in the right atrium or that the synthetic capability of the right atrium is greater than the left atrium. Others have reported repletion of atrial ANF by $\mathrm{d} 3$ of life $(10,25)$. Although these reports did not assess the concentration in the right and left atria separately, all of the data support a rise in atrial ANF concentration between $\mathrm{d} 3$ and 5 of life to a level greater than in the 20-d fetus.

The highest observed concentration of intraatrial ANF was observed on d 15 . We have previously reported an identical pattern in both the Dahl salt-sensitive and salt-resistant animal at the same age (26). The significance of this pattern is not understood.

A number of investigators have reported a greater concentration of ANF in the right than in the left atrium in adult animals (22-24). Studies of the 20-d fetal rat and the 3-wk-old spontaneously hypertensive rat, however, found no difference in the concentration of ANF between the atria (10, 23). Although analysis of the present data in adult animals generated a $p$ value that did not quite reach statistical significance, this study supports and extends the previous findings of equal ANF concentrations in both atria in fetal, newborn, and immature animals.

The concentration in the 20-d fetal rats is three times greater than we have previously reported (9). The only known differences between the experiments are that the measurements in this study were obtained in each atrium from individual animals versus the atria taken as a whole in pooled litter mates.

Due to technical difficulties in harvesting blood from the fetal and newborn animals, we are unable to report simultaneous plasma ANF concentrations. Others, however, have recently reported an identical pattern of change in atrial ANF concentration in the fetal and newborn rat associated with a significant increase in plasma ANF concentration on d 21 of gestation that was maintained for the first $3 \mathrm{~d}$ of life (27). This report is consistent with our data and suggests that the decrease in ANF concentration is a result of greater release than synthesis in the perinatal period.

To conclude, this study documents a significant nadir in the concentration of IR-ANF in the right and left atria during the perinatal period with the highest value observed in immature rats. In contrast to normal adult animals, factors mediating the observed change affect both atria equally. The data support a potential role for ANF in the modulation of intravascular vol at the initiation of extrauterine life. Additional studies are required to explore the relative contribution of changes in ANF synthesis and release during this period and why the perinatal atria respond in concert.

Acknowledgments. The authors thank Ms. Kim Riegel and Ms. Judy Moermond for their excellent assistance in preparing this manuscript.

\section{REFERENCES}

1. Ballerman BJ, Brenner BM 1985 Biologically active atrial peptides. J Clin Invest 76:2041-2048
2. Chapeau G, Gutkowska J, Schiller PW, Milne RW, Thibault G, Garcia R. Genest J, Cantin M 1985 Localization of immunoreactive synthetic atrial natriuretic factor (ANF) in the heart of various animal species. J Histochem Cylochem 33:541-550

3. Weidman P, Hasler L, Gnadinger MP, Lang RE, Uehlinger DE, Shaw S. Rascher W. Reubi F 1986 Blood levels and renal effects of atrial natriuretic peptide in normal man. J Clin Invest 77:734-742

4. Kihara M. Nahayama K, Nakao K, Sugawara A, Morii N, Sakamoto M, Suda M, Shinokura M. Kiso Y, Imura H, Yamori Y 1985 Accelerated natriuresis induced by synthetic atrial natriurctic polypeptide in spontaneous hypertensive rats. Clin Exp Hypertens (A) 7:539-551

5. Kleinert HD 1984 Atrial natriuretic factor inhibits angiotensin, norepinephrinc, and potassium-induced vascular contractibility. Hypertension 6:11431147

6. Yasugima M, Abe K, Kohzuki M, Manno M, Kasai Y, Sato M. Omata K. Kudo K. Tsunoda K, Takeuchi K, Yoshinaga K, Inagami T 1985 Atrial natriuretic factor inhibits hypertension induced by chronic infusion of norepinephrine in conscious rats. Circ Res 57:470-474

7. Kudo T, Barid A 1984 Inhibition of aldosterone production of adrenal glomerulosa by atrial natriuretic factor. Nature 313:756-757

8. Dillinham MA, Anderson RJ 1986 Inhibition of vasopressin action by atrial natriuretic factor. Science 231:1572-1573

9. Dolan LM, Dobrozsi DJ 1987 Atrial natriuretic polypeptide in the fetal rat: ontogeny and characterization. Pediatr Res 22:115-117

10. Wei Y, Rodi CP, Day ML, Wiegand RC, Needleman LD, Cole BR, Needleman P 1987 Developmental changes in the rat atriopeptin hormonal system. J Clin Invest 79:1325-1329

11. Ross MG, Ervin MG, Lam RW, Castro L, Leake RD, Fisher DA 1987 Plasma atrial natriuretic peptide response to volume expansion in the ovine fetus. Am J Obstet Gynecol 157:1292-1297

12. Yamaji T, Hirai N, Ishibashi M, Takaku F, Yanaihara T, Nakayama T 1986 Atrial natriuretic peptide in umbilical cord blood: evidence for a circulating. hormone in the human fetus. J Clin Endocrinol Metab 63:1414-1417

13. Weil J, Bidlingmaier F, Dohlemann C, Kuhnle U, Strom T, Lang RE 1986 Comparison of plasma atrial natriuretic peptide levels in healthy children from birth to adolescence and in children with congenital heart disease. Pediatr Res 20:1328-1331

14. Weil J, Heim JM, Brugmann M, Dohlemann C, Gerzer R 1988 Influence of ANP on the fluid homeostasis. Measurement of plasma and urinary levels of ANP and cGMP in preterm and term infants. Am J Hypertension (abstr) in press

15. Bloch KD, Seidman JG, Naftilan JD, Fallon JT, Seidman CE 1986 Neonata! atria and ventricles secrete atrial natriuretic factor via tissue-specific secretory pathways. Cell 47:695-702

16. Lowry OH, Rosebrough NJ, Farr AL, Randall RJ 1951 Protein measurement with the Folin phenol reagent. J Biol Chem 193:265-275

17. Tang J, Fei H, Xie CW, Suen MZ, Han JS 1984 Characterization and localization of atriopeptin in rat atrium. Peptides (Fayetteville) 5:1173-1177

18. Kittcrman JA, Ballard PL, Clements JA, Mescher EJ, Tooley WH 1979 Tracheal fluid in fetal lambs: spontaneous decrease prior to birth. $J$ Appl Physiol 47:985

19. Epstein M, Loutzenhiser R, Friedland E, Aceto RM, Camargo MJF, Atlas S 1987 Relationship of increased plasma atrial natriuretic factor and renal sodium handling during immersion-induced central hypervolemia in normal humans. J Clin Invest 79:738-745

20. Walsh SZ, Lind J 1970 The dynamics of the fetal heart and circulation and its alteration at birth. In: Stave U (cd) Physiology of the Perinatal Period. Appleton-Century-Crofts, New York, pp 161-163

21. Katsube N, Schwartz D, Needleman P 1985 Release of atriopeptin in the rat by vasoconstrictors and water immersion correlates with changes in right atrial pressure. Biochem Biophys Res Commun 133:937-944

22. Katsube N, Schwartz D, Needleman P 1986 Atriopeptin turnover: quantitative relationship between in vivo changes in plasma levels and atrial content. $\mathrm{J}$ Pharmacol Exp Ther 239:474-479

23. Imada $T$, Takayanagi $R$, Inagami $T 1985$ Changes in the content of atrial natriuretic factor with the progression of hypertension in spontaneously hypertensive rats. Biochem Biophys Res Commun 133:759-765.

24. Cantin M, Genest J 1985 The heart and atrial natriuretic factor. Endocr Rev $6: 107-127$

25. Cantin M, Ding J, Thibault G, Gutkowska J, Salmi L. Garcia R, Genest J 1987 Immunoreactive atrial natriuretic factor is present in both atria and ventricles. Mol Cell Endocrinol 52:105-113

26. Wilson TA, Dolan LM, McCoughran JA, Dobrozsi DJ, Juno CJ, Young CA 1988 Atrial natriuretic factor in the developing Dahl hypertensive rat. Am J Hypertension 1:61-63

27. Castro LC, Arora CP, Parvez S, Hobel CJ, Wade ME 1988 Third Worlc Congress on Biologically Active Atrial Peptides, New York. Hypertensior 1:96 (Abstr) 